Cite this: RSC Adv., 2014, 4, 10779

Received 29th August 2013

Accepted 17th December 2013

DOI: $10.1039 / c 3 r a 44746 d$

www.rsc.org/advances

\section{Ability of co-administered peptide liposome nanoparticles to exploit tumour acidity for drug delivery}

\author{
Shaun C. Offerman, ${ }^{a}$ Anita V. Kamra Verma, ${ }^{b}$ Brian A. Telfer, ${ }^{a}$ David. A. Berk, ${ }^{a}$ \\ David J. Clarke ${ }^{a}$ and Harmesh S. Aojula*a
}

Using a previously-characterised solid tumour model we demonstrate that a mixture of $\mathrm{pH}$ sensitive peptide and liposome nanoparticles (PLNS) can be used to induce payload release in response to small changes in tumour acidity. The classical pH sensitive GALA peptide was modified at two different positions to help tether with preformed liposomes and cause release of calcein marker in response to a less than 1.0 unit drop in $\mathrm{pH}$ from the physiological value. The circular dichroic spectra of the peptide showed that, unlike the GALA sequence, its helical structure was unusually independent of $\mathrm{pH}$ suggesting a different mechanism of action for calcein release. Intravenously-administered PLNs accumulated in tumour tissue in mice, and subjecting the excised tumour tissue slices to low $\mathrm{pH}$ buffer confirmed that these nanoparticles remained $\mathrm{pH}$ responsive. Quantitative in vivo imaging of tumours implanted in mouse dorsal skin allowed real time measurements of nanoparticle accumulation, monitored through Dil labelling of the liposome membrane, and intra-tumour $\mathrm{pH}$ dependent release, monitored by calcein release, to be followed. The release of calcein in the live tumours at their natural acidity of pH 6.8 was further enhanced with MIBG glucose treatment to induce tumour acidification to approximately pH 6.5. Following accumulation a substantially greater and more rapid calcein release was observed in tumours administered with PLNs and subjected to $\mathrm{pH}$-lowering using MIBG treatment, compared to control tumours administered with liposomes lacking the peptide or tumours not treated with MIBG. This work highlights that while PLNs were relatively unresponsive to intrinsic tumour $\mathrm{pH}$, they did have the ability to respond rapidly to extrinsically-induced small changes in $\mathrm{pH}$ near the patho-physiological range.

\section{Introduction}

Development of $\mathrm{pH}$ responsive nanoparticles for controlled drug delivery of chemotherapeutics is scientifically a fast growing area. Although cancer cells vary widely with respect to function and molecular markers, solid tumours are recognised to share certain physiological characteristics, including for example: chronic hypoxia, disorganised neo-vasculature, and a lower extracellular $\mathrm{pH}$ than most normal tissues. ${ }^{1-3}$ Various investigators have sought to exploit these characteristic features of tumour physiology, for example by designing prodrugs that are acid-labile or hydrolysed by specific enzymes. ${ }^{\mathbf{1 , 4}}$ Studies across a range of animal tumour models, and using various measurement techniques, demonstrate that acidification of the tumour extracellular fluid is typical but small in magnitude, with the $\mathrm{pH}$ seldom below a value of 6.5 and usually higher. Hence, "physiological targeting" of tumours based on

${ }^{a}$ Manchester Pharmacy School, The University of Manchester, Manchester, M13 9PL, $U K$

${ }^{b}$ Nanobiotech lab, Kirori Mal College, University of Delhi, Delhi 110007, India extracellular $\mathrm{pH}$, while theoretically possible, presents a highly challenging design problem for drug delivery.

Many polymer based nanoparticles are in development and have shown potential to be comprised into nanosized vehicles for targeting the slightly acidic extracellular microenvironment of solid tumours. ${ }^{5}$ Compared to polymer systems liposomes, being approved clinical products for more than a decade, have a greater appeal, if they can be suitably engineered to respond better in vivo. Use of modified lipids to prepare nanosized lipid vesicles is a well documented strategy for preparing liposomes sensitive to hyperthermia, $\mathrm{pH}$ and enzymes. ${ }^{6-8}$ Although these specifically-modified lipids respond to various stimuli their range of responses in vitro can be far removed from that elicited from the much smaller physiological variations found in vivo. Engineered pH-sensitive liposomes are usually based upon nonbilayer-forming lipids stabilised into bilayer structures at neutral $\mathrm{pH}$ by specific amphiphiles which protonate, in the $\mathrm{pH}$ range of 4.0-6.0, to destabilise the bilayer structure and release the payload. ${ }^{7}$ While this $\mathrm{pH}$ range is ideally suited for intracellular release from endosomes or lysosomes such highly acidic conditions are biologically insignificant elsewhere in tissues. Classical and stealth liposomal formulations of anticancer 
drugs, now in clinical use, both rely on passive targeting ${ }^{9}$ without direct binding to specific cells. In the absence of any receptor-targeting ligand the internalisation of these liposomes is limited. Thus to a great extent the liposome's degradation, and hence drug release, is thought ${ }^{\mathbf{1 0 , 1 1}}$ to occur in the tumour interstitium by a slow process of non-specific degradation., ${ }^{5,12}$ Preceding this process the released drug may be internalised into a cell to elicit a pharmacological response. Highly-stable liposomes, including those used clinically, have a drawback in that drugs may remain entrapped within the liposomes for prolonged periods thereby reducing bioavailability., ${ }^{9,13}$ Stability of $\mathrm{pH}$-sensitive liposomes in the circulation and the ability to release the drug at the tumour site are the two opposing features for which a delicate balance is difficult to conceive using lipid only formulations.

Compared to lipids, amphipathic peptides are an alternative, and more flexible, means of triggering release of drugs from liposomes ${ }^{15}$ over a $\mathrm{pH}$ range. These peptides are yet to be explored in vivo for delivering anticancer drugs. Usually such amphipathic peptides undergo a coil to helix transition to fully integrate with the lipid bilayer and show membrane permeablising (lytic) activity. GALA ${ }^{\mathbf{1 7}}$ is one of the best characterised and is an efficient $\mathrm{pH}$ specific model peptide that shows formation of an alpha helix linked to its lytic activity as the $\mathrm{pH}$ is lowered to 5.0. An analogue of the GALA peptide, with carefully positioned glutamyl residues on the same face of the $\alpha$-helix, succeeded in triggering drug release around $\mathrm{pH} 6$, while retaining drug above pH 6.5 in cell models. ${ }^{18}$ Similarly cholesterol modified GALA, when anchored to a membrane, was able to trigger cytosolic release of rhodamine from internalised liposomes. ${ }^{19}$ However, to exploit the mild acidity found in the tumour interstitium, the peptide mediated release of payload needs to be abrupt and closer to $\mathrm{pH}$ 7.0. Hence we attempted to prepare a mixture of peptide-liposome nanoparticles herein named in short as "PLNs" with an operating $\mathrm{pH}$ shifted more towards the $\mathrm{pH}$ value found in tumours. To do this we modified the GALA sequence at two residues, to help stabilise the helix and assist its integration with the liposomes. As the interaction between peptide and liposome is reversible the study is restricted to exploring whether PLNs, produced by simple preincubation of peptide and liposomes would be able to show targeted release of encapsulated calcein, in the extracellular tumour interstitial fluid where the minimum $\mathrm{pH}$ value may be in the 6.8-6.5 range. The study provides a proof-of concept that liposomes and $\mathrm{pH}$-sensitive peptide when co-administered have the potential to reach the tumour as an integrated nanoparticle assembly that remains $\mathrm{pH}$ responsive in tumour tissues.

\section{Materials and methods}

\section{Materials}

All general chemicals were purchased from Sigma-Aldrich (UK) and Fisher Scientific (UK) unless stated otherwise. $\mathrm{N}^{\alpha}$-Boc-Ala, $\mathrm{N}^{\alpha}$-Boc-Arg (Tos), $\mathrm{N}^{\alpha}$-Boc-Glu (Obzl), $\mathrm{N}^{\alpha}$-Boc-His (Bom), $\mathrm{N}^{\alpha}$-BocLeu, $\mathrm{N}^{\alpha}$-Boc-Trp (CHO), MBHA resin, 2-(1H-benzotriazole-1-yl)1,1,3,3-tetram ethyluronium hexafluorophosphate (HBTU) were purchased from Bachem (UK). The peptide GALA was purchased from AnaSpec. Analogs (Table 1) of GALA, peptide were synthesized manually on a 0.25 mmole scale using $t$-Boc chemistry. For amino acids coupling $3: 3: 9$ equivalents of amino acid, HBTU and $N, N$-diisopropylethylamine (DIPEA) were used allowing 40 minutes for the reaction to complete. Double couplings were performed when necessary as judged by testing the resin with ninhydrin. Peptides 2 and 3 were myristoylated by capping the N-terminal amino with myristic anhydride (3 eq.) in DMF containing DIPEA (6 eq.) base. Resin assembled peptides were pretreated with $20 \%$ piperidine in DMF for 1 hour to remove the formyl group from the tryptophan and then cleaved from the resin with hydrogen fluoride (BOC, $\mathrm{UK})$ in the presence of $p$-thiocresol and $p$-cresol as scavengers. Crude peptides were purified on a C-4 reverse-phase HPLC column (Vydac $21.2 \times 250 \mathrm{~mm}$ ) using a gradient from $30 \%$ acetonitrile-0.1\%TFA to $80 \%$ acetonitrile-0.1\%TFA over 50

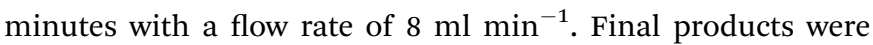
characterised to show HPLC purity in excess of $95 \%$ and $\mathrm{M}+\mathrm{H}^{+}$ values to be within 0.5 unit of the calculated mass as measured by Maldi-TOF (Thermobioanalysis). Peptide concentrations were calculated by absorbance at $280 \mathrm{~nm}$ using an extinction coefficient of $5690 \mathrm{~cm}^{-1} \mathrm{M}^{-1}$.

Liposomes were prepared ${ }^{21}$ by hydrating lipid films, comprising $40: 20: 1$ molar ratio of phosphatidylcholine (Lipid Products, Nutfield, UK) from egg lecithin, cholesterol and 1,1'dioctadecyl-5, 5' -diphenyl-3,3,3', ,3'-tetramethyl indocarbocyanine (DiI) lipophilic tracer (Invitrogen, Netherlands) with a solution of $120 \mathrm{mM}$ calcein prepared in PBS buffer. Following 10 extrusion cycles (Avestin Liposofast 100) at room temperature through $0.1 \mathrm{~nm}$ polycarbonate filters (Nucleopore), non-encapsulated dye was separated by gel filtration using Sepharose CL6B (Sigma) column. Lipid concentration was assayed according to the method by Stewart ${ }^{22}$ and adjusted to $3 \mathrm{mg} \mathrm{ml}^{-1}$. The average hydrodynamic size of liposomes was typically approx. $126 \mathrm{~nm}$ (polydispersity index $<0.2$ ) as determined by dynamic light scattering (DLS) using a Malvern 4700 system (Malvern Instruments Ltd, UK). For determining the interaction of peptide with liposomes, based on tryptophan fluorescence or for testing the haemolytic activity of PLNs, the liposome preparation method was essentially the same except both the calcein and DiI dyes were excluded to avoid any interference. Glucose oxidase (GOX) containing liposomes were prepared using the same method with the substitution of calcein and DiI with 2361 units per ml of GOX enzyme dissolved in $4 \mathrm{ml}$ of hydration buffer.

\section{pH dependent liposome leakage assays}

Peptides (15 nM) were assayed for their ability to release payload by de-quenching of calcein fluorescence from liposomes $(3 \mu \mathrm{M}$ lipid) over the $\mathrm{pH}$ range 6.5 to $7.4 \mathrm{in} 10 \mathrm{mM}$ citrate-phosphate buffer supplemented with $140 \mathrm{mM} \mathrm{NaCl}$. Perkin Elmer LS-50B fluorometer set at an excitation $\lambda$ of $420 \mathrm{~nm}$ and an emission $\lambda$ of $520 \mathrm{~nm}$ was used. 'End point' readings were taken after 10 min, when Triton X-100 (0.1\% w/v) was added and fluorescence after a further min taken as $100 \%$ release $\left(F_{\mathrm{f}}\right)$ against baseline fluorescence of each incubate $\left(F_{\mathrm{i}}\right)$. Percentage calcein release was normalised as $\left[\left(F_{\mathrm{t}}-F_{\mathrm{i}}\right) \times 100\right] /\left(F_{\mathrm{f}}-F_{\mathrm{i}}\right)$, where $F_{t}$ is 
Table 1 Peptide analogues based on primary GALA sequence

Peptide

(1) GALA

(2) C-amidated

(3) N-myristoyl and C-amidated

(4) Glu $19 \rightarrow$ Arg in peptide 3
Sequence

WEAALA EALAEALAEHLAEALAEALEALAA

WEAALA EALAEALAEHLAEALAEALEALAA- $\mathrm{NH}_{2}$ Myr-WEAALA EALAEALAEHLAEALAEALEALAA- $\mathrm{NH}_{2}$ Myr-WEAALA EALAEALAEHLARALAEALEALAA- $\mathrm{NH}_{2}$ fluorescence at time $(t=10 \mathrm{~min})$ after addition of the peptide. The lysis of the GOX liposomes ( $10 \mu \mathrm{g}$ lipid) was followed by the addition of $0.5 \mathrm{ml}$ solution A $(300 \mathrm{mg}$ glucose and $200 \mathrm{I} . \mathrm{U}$ of horse radish peroxidase) and $0.5 \mathrm{ml}$ of solution $\mathrm{B}\left(20 \mathrm{mg} \mathrm{ml}^{-1}\right.$ 5 -amino salicylic acid), both in $50 \mathrm{mM}$ phosphate buffer at $\mathrm{pH}$ 6.0. Absorbance was recorded continuously at $450 \mathrm{~nm}$ after the addition of peptide or Triton X-100.

\section{Peptide-liposome nanoparticles (PLNs)}

The association of the peptide with liposomes was characterised by an increase in tryptophan fluorescence emission at $340 \mathrm{~nm}$ when excited at $280 \mathrm{~nm}$ using Perkin Elmer LS-50B fluorometer. Spectra were corrected for background by subtracting any signal from liposomes and buffer alone. PLNs were prepared by adding peptide $(2.2 \mu \mathrm{M})$ to a constantly stirred solution of liposomes (1.9 mM lipid) in phosphate-buffered saline (PBS) containing 5 mM HEPES pH 7.4 and 1 mM EDTA over 5 minutes. Myristoyl residue on the $\mathrm{N}$-terminal is important for anchoring the peptide to form a complex with liposomes. The size and the polydispersity index of PLNs was characterised by DLS using the Malvern 4700 (UK-Malvern, Nano series ZS) Zeta Sizer. Measurements were performed in a clean four sided quartz cuvette containing PLNs in filtered ( $0.22 \mu \mathrm{m}$ filter, Millipore, SLGP R25 LS) buffer. Samples were allowed to equilibrate for 5 minutes before the intensity weighted mean diameter ( $z$-average diameter) were determined by averaging five runs for each sample.

To test the lytic activity PLNs, at different time intervals and over a range of $\mathrm{pH}$ values, the PLNs were immediately diluted 10 fold for loading into the dispenser unit. Labsystems Fluoroskan (Ascent FL) then dispensed $10 \mu \mathrm{l}$ of the aliquots at $20 \mathrm{~min}$ time intervals into wells containing $180 \mu \mathrm{l}$ of buffer $(10 \mathrm{mM}$ sodium citrate phosphate supplemented with $140 \mathrm{mM} \mathrm{NaCl}, 5 \mathrm{mM}$ HEPES and $1 \mathrm{mM}$ EDTA) adjusted to pH 7.4, 6.8, 6.5 and 6.0. Fluorescence intensity in each well was read (Ex $485 \mathrm{~nm}$ Em $535 \mathrm{~nm}$ ) at a fixed time of $10 \mathrm{~min}$ after each dispensing. A series of wells containing either liposomes only or Triton were added to determine background and $100 \%$ lysis respectively. Four replicates were used for each determination. For testing, in presence of plasma, the method was essentially the same except testing time periods were longer and the PLNs were pre-treated with equal volume of freshly prepared mouse plasma before any dilution took place to load the dispenser.

\section{Circular dichroism spectroscopy}

CD spectra were taken on a Jasco J810 spectropolarimeter at $0.2 \mathrm{~nm}$ intervals over the wavelength range $200-250 \mathrm{~nm}$ and with $0.1 \mathrm{~mm}$ path length cells (Hellma) at $25^{\circ} \mathrm{C}$. Samples in the same $10 \mathrm{mM}$ citrate phosphate-buffered saline at $\mathrm{pH} 5.0$ and 7.4 were scanned three times at $40 \mathrm{~nm}$ per minute with a time constant of $1 \mathrm{~s}$. The CD spectra in low salt buffers were carried out using $5 \mathrm{mM}$ Tris piperazine buffer at various $\mathrm{pH}$ values adjusted with $0.3 \%$ perchloric acid. ${ }^{43}$ Following averaging and correction for background by subtracting the spectrum without peptide, data was expressed as mean residue molar ellipticity, from which the helix content was estimated. ${ }^{23}$

\section{Epifluorescence imaging}

In vivo and in vitro imaging was performed with a Nikon E800 microscope equipped for epifluorescence with a 100 Watt mercury lamp attenuated by a ND-16 filter. A multiple-band dichroic mirror and barrier filter (Chroma Technology Corp, model 61002) allowed the observation of red (600-650 nm) DiI fluorescence and green $(520-540 \mathrm{~nm})$ calcein fluorescence. An appropriate single-band excitation filter (490 or $570 \mathrm{~nm}$ narrow band-pass) was moved into the illumination path by computercontrolled filter wheel. Images were projected onto a scientificgrade CCD camera (Micro-max, Princeton Instruments) and captured at intervals of 30 to 60 seconds with a typical exposure time of $100 \mathrm{~ms}$ per image over a typical period of 30 minutes. In the intervals between images, an electronic shutter blocked the illumination path to minimise photo-damage. Automated data acquisition routines were written using imaging control software (MetaMorph $®$, Universal Imaging) to program the operation of the lamp filter wheel and shutter for selecting of fluorescence excitation, operation of the CCD camera and analysis of images. The following calculations were performed in real time: subtraction of background intensity levels; calculation of mean, maximum, and variance of fluorescence intensity; relative change in intensity for each fluorescence channel; and ratio of intensities at different wavelengths.

\section{Clearance from blood circulation of PLNs}

Female C3H mice (8 to 10 weeks, $20-25 \mathrm{~g}$ ) were divided into groups each of 3 mice. Calcein-DiI liposomes were injected $(200 \mu \mathrm{l})$ into the tail vein of each mouse at a dose of $0.8 \mu$ mole lipid. Blood samples $(0.1 \mathrm{ml})$, collected under terminal anaesthesia by cardiac puncture at various time intervals, were diluted with PBS pH 7.4 buffer $(1 \mathrm{ml})$ and centrifuged for $1 \mathrm{~min}$ at $13000 \mathrm{~g}$. Supernatant $(0.5 \mathrm{ml})$ was taken and diluted into $2 \mathrm{ml}$ of PBS pH 7.4, when calcein fluorescence was monitored before and after Triton X-100 $(0.1 \% \mathrm{v} / \mathrm{v})$ treatment using the Perkin Elmer LS-50B fluorometer. 


\section{Haemolytic assays}

A $100 \mu \mathrm{l}$ aliquot of washed erythrocytes $\left(3.45 \times 10^{8}\right.$ cells per $\left.\mathrm{ml}\right)$ was placed into an Eppendorf containing $800 \mu \mathrm{l}$ of buffer (10 mM citrate phosphate $\mathrm{pH} 7.4$ supplemented with $140 \mathrm{mM}$ $\mathrm{NaCl}, 5 \mathrm{mM}$ Hepes and $1 \mathrm{mM}$ EDTA). To this was added $100 \mu \mathrm{l}$ of test samples containing $4 \mu \mathrm{M}$ peptide, except for controls which were either $100 \mu \mathrm{l}$ buffer or $100 \mu \mathrm{l}$ of $10 \%$ Triton X-100. Each Eppendorf was incubated for 30 minutes before being centrifuged ( 5 minutes at $1500 \mathrm{rpm}$ ). Aliquots of $200 \mu \mathrm{l}$ of supernatant were then transferred to a 96 microwell plate (costar) and the Absorbance recorded at $550 \mathrm{~nm}$ on a Tecan Safire microwell plate reader.

\section{pH sensitivity of PLNs accumulated in excised tumours}

KHT and radiation-induced fibrosarcomas (RIF-1) cell lines were kindly donated by The Experimental Oncology Group, Manchester University, UK. The cells in T75 flasks were cultured at $37{ }^{\circ} \mathrm{C}$ in $5 \%$ carbon dioxide atmosphere in Dulbecco's modified Eagle's medium (DMEM Sigma) containing antibiotics and supplemented with $10 \% \mathrm{v} / \mathrm{v}$ heat-inactivated foetal calf serum (FCS Sigma) and $2 \mathrm{mM}$ L-glutamine. Once cells were $90 \%$ confluent they were treated with $0.05 \%$ trypsin in EDTA for 15 min with gentle agitation. The cells were then gently centrifuged $1800 \mathrm{rpm}$ for 10 minutes, and resuspended in $1 \mathrm{ml}$ of DMEM. C3H syngenic mice (8-10 weeks old and weighing 20$25 \mathrm{~g})$ were each subcutaneously injected with $5 \times 10^{6}$ cells $(0.1 \mathrm{ml})$ on their dorsal side to initiate tumour growth. After 13 days, when size of tumours reached between 200 and $400 \mathrm{~mm}^{3}$, PLNs or liposomes at a dose of $0.8 \mu$ mole lipid were administered into the tail vein. After 3 hours, tumours were aseptically excised and transferred into PBS pH 8 buffer and sliced into thin sections $(60-100 \mu \mathrm{m})$. Each slice, mounted in a perfusion chamber on the microscope stage, was bathed with PBS buffer of pH 8. The microscope was fitted with epifluorescence optics, positioned to image and monitor epifluorescence. The perfusion buffer was replaced with $10 \mathrm{mM}$ citrate-phosphate buffer at pH 5.8 and epifluorescence imaging continued.

\section{Intra-tumoral pH measurements}

In order to lower tumour $\mathrm{pH},{ }^{\mathbf{1 6}}$ mice were given intra-peritoneal doses of $40 \mathrm{mg} \mathrm{kg}^{-1}$ meta-iodobenzylamine (MIBG) and $1.5 \mathrm{~g} \mathrm{~kg}^{-1}$ D-glucose dissolved in PBS. Control mice received the same volume $(0.2 \mathrm{ml})$ of saline solution. One hour later, the mice were anaesthetized with Hypnorm-midazolam, when intra-tumoral $\mathrm{pH}$ was estimated by inserting into each tumour a needle (20G) microelectrode (tip diameter 0.89 mm; model 818; Diamond General, Ann Arbor, MI).

\section{Window-chamber in vivo measurements}

The dorsal skin flap window chamber model ${ }^{10,24-26}$ with RIF allografts, known to be more MIBG-sensitive than KHT tumours, was used to evaluate the PLNs in vivo performance with respect to calcein release. A small piece ( $\sim 1 \mathrm{~mm}$ cube) of tumour tissue (RIF-1) was implanted in a dorsal skin fold of each mouse. After 7-10 days, the tumour in the chamber typically grew to 2-3 $\mathrm{mm}$ in diameter and blood flow was visible in new tumour blood vessels. Mice were similarly treated with either MIBG/glucose or saline (control), 3 hours prior to IV treatment (0.4 $\mu$ mole lipid) with PLNs or liposomes (control). Throughout mice were kept anaesthetized (Hypnorm/pentabarbitol/water) on a warmed microscope stage. Skin fold chambers were viewed through a $4 \times($ NA 0.13 ) objective. Transilluminated brightfield images of small tumour vasculature networks with brisk blood flow were recorded using halogen lamp. Epifluorescence illumination was realised as described in the previous section. Tissue auto-fluorescence under the same exposure conditions were subtracted from the measured epifluorescence intensities. Release kinetics were recorded as intensity versus time for each of the two fluorescence channels. Normalised dual fluorescence ratiometric kinetic plots were computed as:

$$
\text { Normalised release }=\frac{I_{\text {contents }}(t) / I_{\text {contents }}\left(t_{0}\right)}{I_{\text {lipo }}(t) / I_{\text {lipo }}\left(t_{0}\right)}
$$

where $I_{\text {contents }}$ is calcein fluorescence intensity while $I_{\text {lipo }}$ is the DiI intensity. The ratio immediately after injection (i.e., when the step increase in tissue fluorescence occurred) was taken as 1. Using the normalised fluorescence ratio, any changes in fluorescence associated with accumulation or clearance of liposomes are minimised or ruled out. Changes in the ratio can thus be taken to reflect release of liposome contents.

All experiments involving animals were approved by local ethics committees and carried out according to the Scientific Procedure Act 1986 under the Home Office License 40/2082 (Manchester).

\section{Results \& discussion}

\section{Design \& lytic activity}

Peptides which are able to lyse liposomes are generally regarded unsafe for use in drug delivery due to their cytolytic action and toxicity towards healthy cells. Recently reports have suggested that lipopeptides, when integrated with liposomes, may succeed in overcoming such limitations. Lin et al. ${ }^{27}$ succeeded in demonstrating that GALA peptide modified on the $\mathrm{N}$ terminal with fatty acyl chains (palmitoyl or lauryl) became considerably more lytic towards liposomes and yet did not impair cell viability. As a further example Etzerodt et $a .^{28}$ prepared a dimyristoyl GALA analogue and incorporated this into liposomes in stable form with relatively little fusion at $\mathrm{pH}$ 7.4 and above. Such studies offer assurance for safer design of efficient drug delivery systems in which peptide and liposomes are combined to constitute multifunctional nanoparticles with lower toxicity.

The modification of the GALA sequence (Table 1) in this study included N-terminal myristoyl modification, substitution of glutamate-19 with arginine and C-terminal amidation. Peptides were $>95 \%$ pure and characterised by mass spectrometry. An Arg residue was strategically placed towards the centre of the sequence with the expectation that this may aid 
salt bridge formation with the Glu residues located near by, on the same face of the amphipathic helix.

To predict and compare, peptide $\mathrm{P} 4$ with the GALA sequence, AGADIR algorithm ${ }^{29}$ was used to simulate the $\mathrm{pH}$ dependence profile of their helix contents (Fig. 1a). The software allows the option of the $\mathrm{N}$ terminal to be capped with an acetyl group and the $\mathrm{C}$ terminal to amidated. In line with the $\mathrm{p} K_{\mathrm{a}}$ values of glutamyl residues the GALA peptide exhibited transition to higher helical content at $\mathrm{pH}$ values below 5.5. In contrast a close analogue of $\mathrm{P} 4$, with the N-terminal acetylated rather than myristoylated was predicted to yield an even higher helix content $(\sim 90 \%)$ that remained almost independent of $\mathrm{pH}$.

The secondary structure of the $\mathrm{P} 4$ peptide studied by $\mathrm{CD}$ spectroscopy (Fig. 1b) gave minima at $208 \mathrm{~nm}$ and $222 \mathrm{~nm}$, suggestive of a right-handed $\alpha$-helical conformation. Using the method of Chen et al. ${ }^{23}$ the helix content is estimated to be $93 \%$ at pH 7.4 and this value, consistent with the above predicted $\mathrm{N}$ terminally capped structure, did not increase significantly on lowering the $\mathrm{pH}$ to 5 .

This remarkably high degree of helix content independent of acidity is distinct from GALA $^{30}$ which is well documented to rely on $\mathrm{pH}$ dependent coil to helix transitions for lytic activity. The central location of Arg residue substitutes the $\mathrm{i} \rightarrow \mathrm{i}+4$ destabilising electrostatic repulsion between Glu residues with a stabilising salt bridge involving Glu15 and Arg19 side chains.

Overall this may assist in stabilising helical conformation on both the $\mathrm{N}$ - and C-terminal segments. The use of a high salt concentration in co-ordinating buffers can often hinder detection of small changes in conformation. For this reason the CD spectra for $\mathrm{P} 4$ were also recorded in $5 \mathrm{mM}$ Tris piperazine buffer and compared to the GALA peptide under identical conditions. While the GALA peptide exhibits the expected acid induced helix formation, the P4 peptide did not show appreciable (Fig. 7) dependence of ellipticity on $\mathrm{pH}$. It is thus unlikely that changes in helical structure due to lowered acidity contribute to induced lysis of liposomes closer to the physiological $\mathrm{pH}$.

The lytic activity of the peptide $\mathrm{P} 4$, at a lipid to peptide ratio of $(200: 1)$, was evaluated by following release of entrapped calcein from liposomes over a 10 minute period at different $\mathrm{pH}$ values as shown in Fig. 2. All peptides were inactive at pH 7.4. As expected, simply C-terminal amidated GALA (P2), was poorly lytic over the entire range $\mathrm{pH} 6.5$ to 7.4 whereas the myristoyl analogue P3 displayed significant activity ( $\sim 15 \%$ release) at $\mathrm{pH} 6.5$.

This observation is consistent with reports showing that the triggering range for GALA is below $\mathrm{pH} 6.5$ and that modification of lytic peptide with myristoyl residue can increase its lytic activity. ${ }^{20,21,27}$

The greatest lytic activity was shown by the newly designed myristoyl and arginine modified peptide (P4) with a substantial $(>70 \%)$ release at $\mathrm{pH} 6.5$ and appreciable $(\sim 32 \%)$ release at $\mathrm{pH}$ 6.8. The exact mechanism of calcein release by the peptide is not clear. In comparison to GALA a combination of helix stabilisation, lower negative charge and the ability of the myristoyl modification to encourage association with liposomes may all account for the observed increased lytic activity as well as the shift of the onset of lytic activity towards the physiological $\mathrm{pH}$. The increase in helix content has been noted before ${ }^{27,28}$ for other fatty acid modified GALA type sequences including dimyristoylGALA, palmitoyl-GALA, lauryl-GALA.

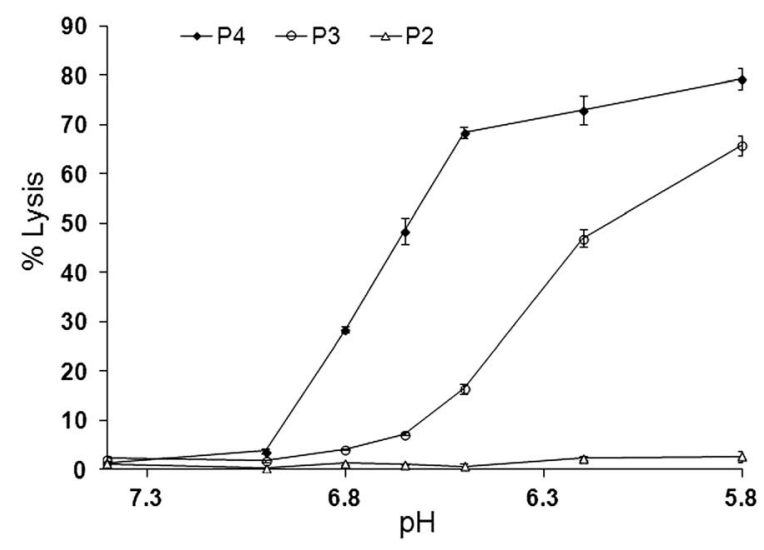

Fig. 2 pH dependent calcein release from liposomes was induced by adding GALA peptide analogues (15 nM) to calcein liposomes ( $3 \mu \mathrm{M}$ lipid). The \% lysis was calculated from calcein release after 10 minutes of incubation with the peptides in $10 \mathrm{mM}$ citrate-phosphate buffer supplemented with $140 \mathrm{mM} \mathrm{NaCl}$. Each determination was conducted in triplicate.
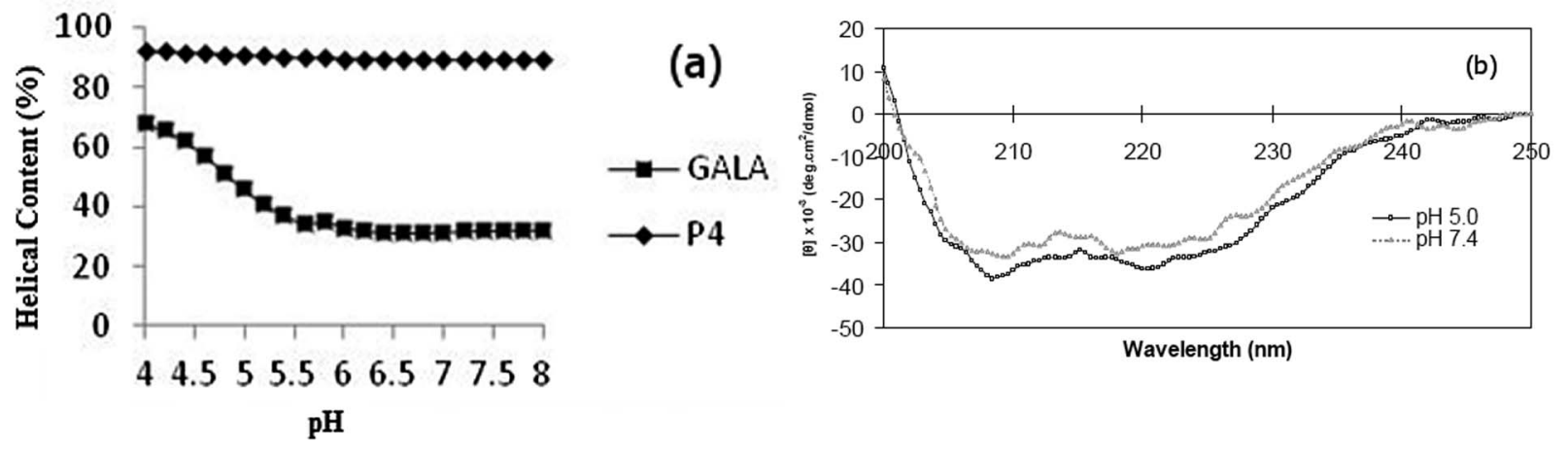

Fig. 1 (a) Predicted pH profile of helix content using Agadir algorithm and (b) observed $\mathrm{CD}$ spectra at $\mathrm{pH} 7.4$ and $\mathrm{pH} 5.0$ in $10 \mathrm{mM}$ citrate phosphate-buffered saline. Spectra were averaged and corrected for background by subtracting the spectrum without peptide. 
The ability to promote substantial release of calcein in mildly acidic buffer is a key characteristic for the functioning of PLNs close to physiological range. Consequently $\mathrm{P} 4$ was considered as a suitable candidate for assimilating PLNs and demonstrating release of payload in response to tumour microenvironment.

\section{Association of P4 with liposomes}

The association of the GALA peptide with phosphatidylcholine liposomes composed from egg yolk lecithin and cholesterol can be inferred from changes in tryptophan fluorescence emission intensity. ${ }^{17,30}$ Incubation of peptide $\mathrm{P} 4$ with liposomes for five minutes resulted in an increase in fluorescence emission at $\mathrm{pH}$ 7.4 indicating its insertion into a non-polar environment (Fig. 3).

Hence at $\mathrm{pH} 7.4$ the peptide $\mathrm{P} 4$ appears to have the ability to integrate with liposomes. This is in sharp contrast to GALA that is reported not to exhibit such an increase at the same $\mathrm{pH}$ as a reflection of its inability to form a complex with liposomes. ${ }^{30}$ Extended incubation time with liposomes did not appreciably change the fluorescence emission suggesting that the insertion into the lipid bilayer is rapid and largely takes place within the first five minutes.

At a $\mathrm{pH}$ value of 6.5 where the peptide is lytic against liposomes (Fig. 2) a slight increase in fluorescence intensity is again observed but this is also accompanied by a $\sim 4 \mathrm{~nm}$ blue shift in $\lambda_{\max }$ indicative of an enhanced hydrophobic environment at low $\mathrm{pH}$. To form a non-lytic complex between liposomes and peptide at $\mathrm{pH} 7.4$ their respective ratios were altered to reach an optimum at which PLNs show little or no leakage at pH 7.4, over a longer period of time, while exhibiting a relatively higher degree of lysis at acidic $\mathrm{pH}$. For peptide $\mathrm{P} 4$ the optimum lipid to peptide ratio was found to be $864: 1$. Fig. 4 and 8 show the stability of this preparation. Dynamic light scattering was used to characterise these PLNs. The $Z$-average diameter was 127.5 $\mathrm{nm}$ and almost independent (Table 2) of $\mathrm{pH}$. Liposomes without peptide also showed a comparable diameter around $126.2 \mathrm{~nm}$. Liposomes associated with peptide are thus likely to

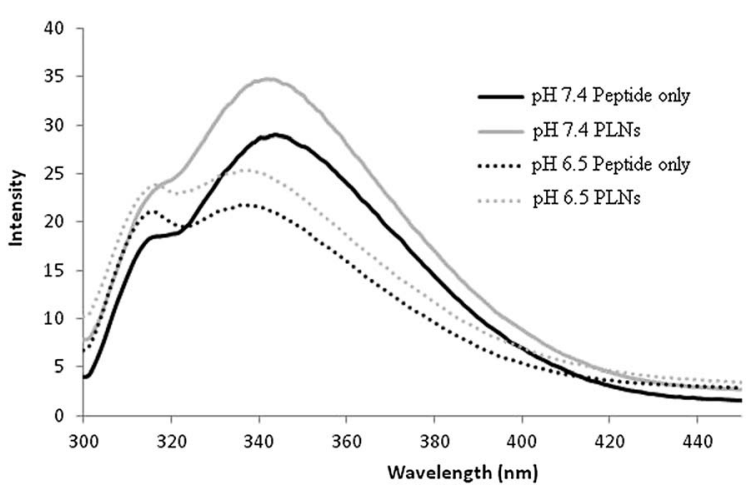

Fig. 3 Fluorescence emission spectra of $\mathrm{P} 4$ peptide $(1.5 \mu \mathrm{M})$ at $\mathrm{pH} 7.4$ (-) and pH 6.5 (---) and after incubation with liposomes (3 $\mu \mathrm{M}$ lipid) at pH 7.4 (一) and pH 6.5 (---). Spectra were recorded in $10 \mathrm{mM}$ sodium citrate phosphate buffer supplemented with $140 \mathrm{mM} \mathrm{NaCl}, 5 \mathrm{mM}$ Hepes and $1 \mathrm{mM}$ EDTA and corrected for background signal from buffer and liposomes. Excitation wavelength was $280 \mathrm{~nm}$.

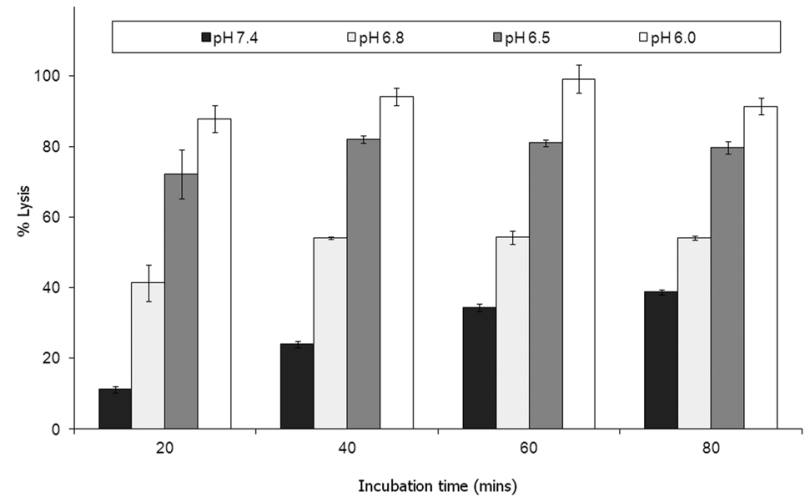

Fig. 4 Calcein-Dil liposomes at lipid to peptide ratio of $864: 1$ were dispensed $(10 \mu \mathrm{l})$ into micro-wells containing $180 \mu \mathrm{l}$ of buffer comprising $10 \mathrm{mM}$ sodium citrate phosphate supplemented with 140 $\mathrm{mM} \mathrm{NaCl}, 5 \mathrm{mM} \mathrm{HEPES}$ and $1 \mathrm{mM}$ EDTA and adjusted to $\mathrm{pH} 7.4,6.8,6.5$ and 6.0. Fluorescence emission was recorded (Ex $485 \mathrm{~nm}$ Em $535 \mathrm{~nm}$ ) at 20 minute intervals. Percent lysis was calculated using data from a series of wells containing either liposomes only ( $0 \%$ lysis) or liposomes with Triton X-100 (100\% lysis) treated in similar manner to PLNs. The mean of 4 replicates is presented.

be reasonably stable with regards to their particulate nature without evidence of fusogenic activity. PLNs incubated for 20 minutes at $\mathrm{pH} 7.4$ did not show any significant change in size with an average diameter of $125.9 \mathrm{~nm}$ and retained their homogeneity with a polydispersity value of 0.168 .

Parente $e t ~ a l .{ }^{31}$ also reported no $\mathrm{pH}$ dependent increase in light scattering signal for liposomes where diameters exceed 50 $\mathrm{nm}$ when exposed to GALA. An identical observation has recently ${ }^{28}$ been made for dimyristoyl-GALA associated with $106 \mathrm{~nm}$ diameter POPC liposomes. Fig. 4 compares the stability of the resulting PLNs by following calcein release. The PLNS became unstable, releasing calcein, as the $\mathrm{pH}$ was lowered and time increased. At physiological pH a $22 \%$ background lysis is seen over 40 minutes.

As lytic activity is dependent on peptide concentration this level of leakage at $\mathrm{pH} 7.4$ can in practice be reduced further by increasing the lipid to peptide ratio. However such an action would also significantly reduce the overall \% lysis at acidic values yielding less $\mathrm{pH}$ responsive PLNs.

Nevertheless for animal studies it is paramount to reduce any undue lysis as much as possible without significantly compromising the response to $\mathrm{pH}$. Lin et al. $^{27}$ tested the cytotoxic action of a fatty acid modified GALA analogue in cell culture media and found that there was little or no effect on viability. The authors argued that one reason for this may be that the lipopeptide could be buffered by the serum proteins.

Table 2 Average diameters and polydispersity index as determined by DLS

\begin{tabular}{lllll}
\hline Sample & $\begin{array}{l}\text { pH 7.4 } Z \text {-ave } \\
(\mathrm{nm})\end{array}$ & $\begin{array}{l}\mathrm{pH} 7.4 \mathrm{PdI} \\
(\%)\end{array}$ & $\begin{array}{l}\mathrm{pH} \mathrm{6.0} \mathrm{Z-ave} \\
(\mathrm{nm})\end{array}$ & $\begin{array}{l}\mathrm{pH} \text { 6.0 PdI } \\
(\%)\end{array}$ \\
\hline Liposomes & 126.2 & 0.146 & 126.9 & 0.168 \\
PLNs & 127.5 & 0.195 & 123.9 & 0.122
\end{tabular}


On this basis we would also expect the small \% of undue leakage at $\mathrm{pH} 7.4$ to become negligible in the presence of serum proteins.

Indeed when the PLNs prepared above were incubated with mouse plasma for various lengths of time and then re-evaluated (Fig. 8), we noted very little lysis at physiological pH. More importantly the PLNs remained $\mathrm{pH}$ responsive, albeit less so at pH 6.8 than before.

Cytolytic peptides can be haemolytic, causing cytotoxicity. To further test toxicity haemolytic assays were carried out. The overall \% lysis was found to be low for P4 (<6\%) (Fig. 5) and this was further reduced for PLNs indicating that the peptide was less accessible to erythrocytes. This would be expected if the peptide became associated with liposomes. The small \% lysis seen for $\mathrm{P} 4$ implies the peptide is able to permeabilise cell membranes and release large molecules. The parent peptide GALA is known $^{31}$ to form discrete pores that permit only small molecules, less than 800 molecular weight, to leak from liposomes.

On this basis, GALA peptide would not be expected to release haemoglobin from erythrocytes. Indeed the haemolytic activity of GALA peptide is negligible compared to P4 (Fig. 5). The lytic activity of GALA on liposomes is well known to be significantly impaired $^{\mathbf{4 1}}$ by presence of cholesterol at more than $30 \%$ molar excess over the lipid concentration. Hence the mechanism of action for these two peptides must be very distinct. In order to investigate this further, liposomes composed of egg PC and cholesterol at a 2:1 molar ratio and encapsulating a large molecular weight protein marker, glucose oxidase (GOX), were tested against both the GALA peptide and P4. The release of GOX was continuously followed using a colorimetric assay of the enzyme activity. As expected the GALA peptide did not reveal any leakage of GOX when compared to liposomes alone (Fig. 6). In contrast when the peptide $\mathrm{P} 4$ is added an immediate increase in activity is noticed as lysis occurs to release the enzyme. To release such large molecules of the size of GOX $\left(M_{\mathrm{w}}\right.$ $160 \mathrm{kDa}$ ) it is highly likely that the peptide $\mathrm{P} 4$ is acting as a surfactant-like membrane disrupter rather than a discrete pore former. Indeed myristoylation of the peptide will favour micelle formation at low $\mathrm{pH}$.

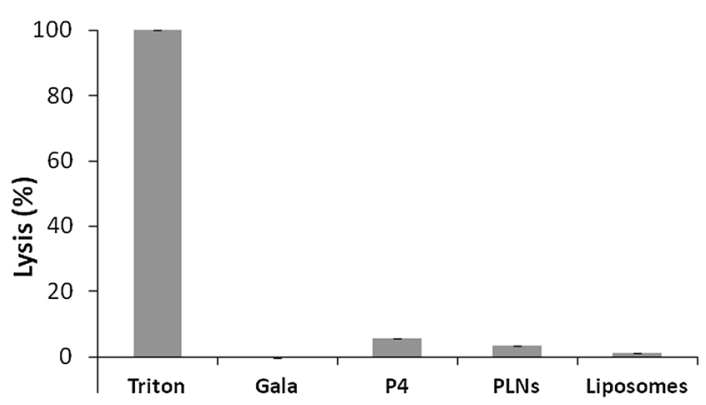

Fig. 5 Comparison of the haemolytic activity of peptides and liposomes. Erythrocytes incubated with $0.4 \mu \mathrm{M}$ of peptides or PLN's were spun and the absorbance of the supernatant recorded at $550 \mathrm{~nm}$. The $\%$ lysis was normalised to $100 \%$ using Triton and using buffer to represent 0\% lysis.

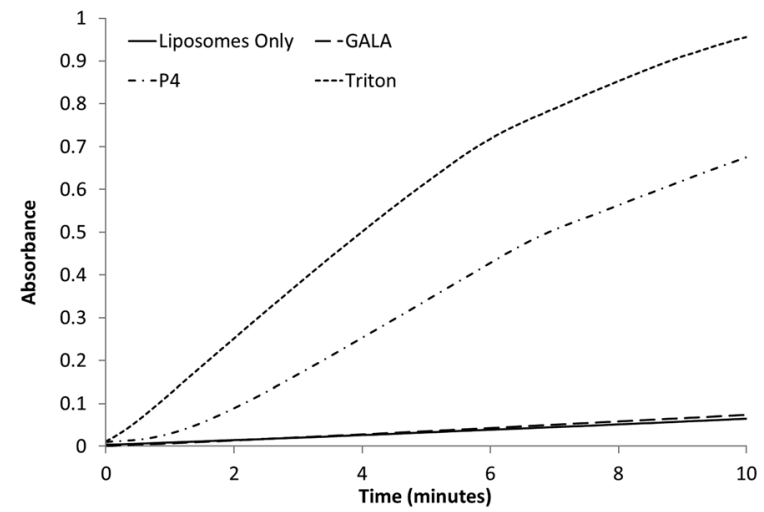

Fig. 6 Colorimetric assay following the release of GOx from egg PC : Ch liposomes with the addition of $0.1 \mu \mathrm{M}$ peptide or $1 \%$ Triton. A baseline of liposomes only was recorded for comparison.

In line with this Lin et $a .^{27}$ found that GALA is unable to release dextran of molecular weight $4 \mathrm{kDa}$ while lauryl-GALA can efficiently release this payload by self-assembling into micelles in the low $\mu \mathrm{M}$ range.

Since the secondary structure of the $\mathrm{P} 4$ is not appreciably affected by $\mathrm{pH}$ (Fig. $1 \mathrm{~b}$ and $7 \mathrm{~b}$ ) the mechanism of membrane disruption may be predominately governed by the increased net hydrophobicity of the peptide as $\mathrm{pH}$ is lowered. This does not however explain why the peptide's $\mathrm{pH}$ of activation is shifted towards a value of $\mathrm{pH}$ 6.8. In the $\mathrm{P} 4$ sequence the Glu residues are strategically placed to adopt an almost ideal amphipathic helix which is stabilised by the Glu-Arg salt bridge. Such a structure, especially when in hydrophobic environment or when in association with membranes, assisted by the increased solubility in bilayer due to myristoyl residue, can be expected to have perturbed $\mathrm{p} K_{\mathrm{a}}$ values for Glu residues which are upshifted towards neutral $\mathrm{pH}$. It is not uncommon for charged residues in amphipathic helices to have the $\mathrm{p} K_{\mathrm{a}}$ values of their side chains significantly different from free amino acids. ${ }^{4}$ For the GALA peptide it would be energetically unfavourable to transfer a net negative charge of -6.9 into the bilayer. The end capping of charged termini on $\mathbf{P} 4$ helps reduce the net negative charge to -4.9 and this together with myristoyl residue promoting interaction with lipid bilayer may provide sufficient driving force to tether the amphipathic helix with the membrane. In this state partially buried Glu residues will be expected to have higher a $\mathrm{p} K_{\mathrm{a}}$ than free Glu residues due to loss of hydration. ${ }^{\mathbf{4 2}}$ This would allow Glu residues to function as hydrogen acceptors much closer to the physiological range. On the other hand the GALA peptide which is not able to embed within the membranes at $\mathrm{pH} 7.4$ in its non-helical form will lack these effects. There is some evidence that the $\mathrm{P} 4$ peptide may have tendency to self-associate even in aqueous buffers when devoid of high salt concentration. This is apparent from the ratio of ellipticity values at $222 \mathrm{~nm}: 208 \mathrm{~nm}$ being greater than unity (Fig. 7).

When the helix is stabilised in much lower dielectric constant media as within the membrane, the negative charge repulsion at $\mathrm{pH} 7.4$ from glutamate residues will be sufficient to 

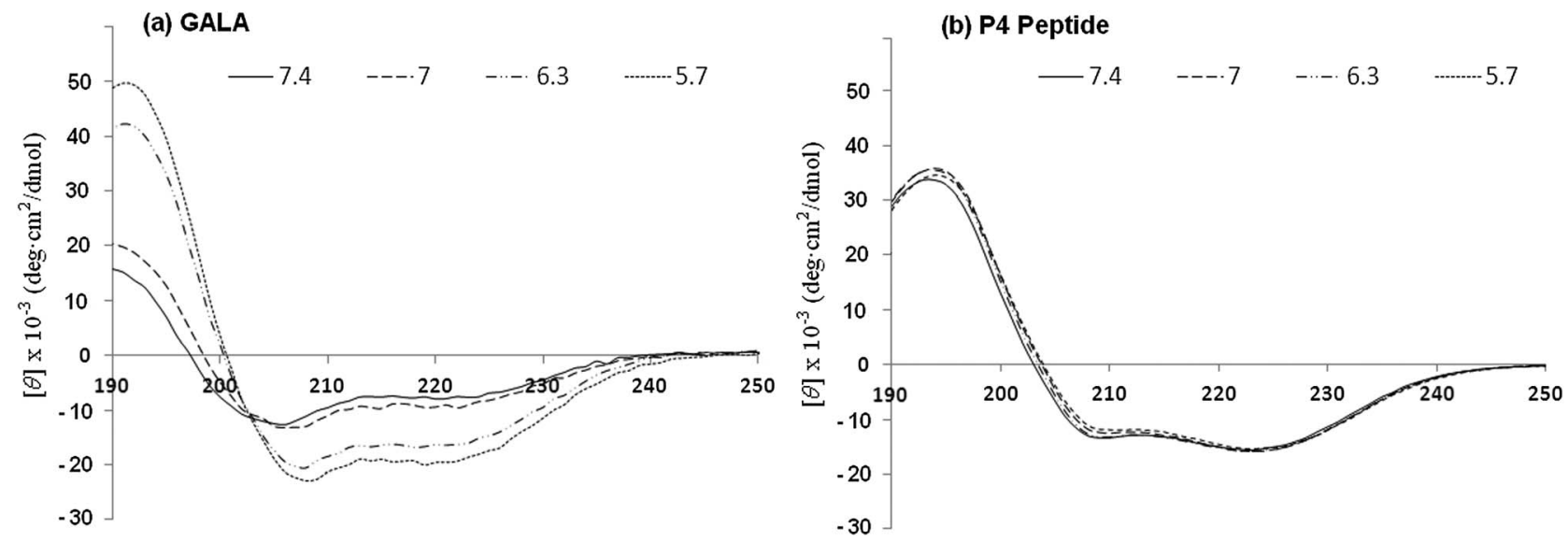

Fig. 7 CD spectra for GALA (a) and P4 (b) peptides in $5 \mathrm{mM}$ Tris piperazine buffer at different pH values.

provide counter-balancing destabilising forces acting to prevent further intermolecular association of peptides needed for micelle formation. However on mild acidification, the loss of negative charges will render P4 significantly more hydrophobic in the helical form. The increased hydrophobicity alone may allow the helices bearing myristoyl residue to selfassociate further and cause bilayer disruption through micellization. This may explain why the rate of release of GOX from liposomes by P4 and triton were both high (Fig. 6) as can be expected from the micellization process. Moreover the blue shift in fluorescence emission at pH 6.5 (Fig. 3) is an indication that the peptide may have a different state of aggregation when in the active state.

\section{Retention of $\mathrm{pH}$ sensitivity when accumulated in excised tumour slices}

While recognising that a simple mixture of peptide and liposomes (PLNs) is only transiently stable and not robust enough to constitute a pharmaceutical drug delivery formulation, the over four hour stability period seen in plasma (Fig. 8) does provide an adequate time window to evaluate their response to $\mathrm{pH}$, in vivo, as a proof of concept.

Clearance rates of the liposome used for PLNs in mice, assayed by total calcein fluorescence, gave a characteristic profile with a half-life of 2.5 hours (Fig. 9). This circulation time for the given particle size $(\sim 127 \mathrm{~nm})$ should allow sufficient accumulation in the tumour to be able to follow calcein release in real time..$^{32,33}$

Studies were thus carried out to determine whether the PLNs remain "intact" in vivo, such that they would continue to exhibit a pH-triggered release of contents. $\mathrm{KHT}^{34}$ fibrosarcoma allograft was used for this experiment as its extracellular $\mathrm{pH}$ is reported to be slightly above neutral ${ }^{35}$ to allow accumulation of PLNs without provoking any significant calcein release. Three hours were allowed for accumulation of PLNs in the KHT allograft tumours before excising the tissue and placing in a perfusion chamber. Intensely-green, de-quenched calcein fluorescence became evident when the perfusion buffer was acidified to $\mathrm{pH}$ 5.8 (Fig. 10B), compared to images at physiological pH 7.4
(Fig. 10A) or when calcein-DiI liposomes alone were used without the peptide P4 (Fig. 10C and D).

These observations indicate that a significant portion of the PLNs that accumulated in the tumour mass remained intact within the tumour tissue and responsive to extracellular $\mathrm{pH}$. The results also suggest that the extracellular $\mathrm{pH}$ of the KHT tumour allografts in situ was not sufficiently acidic to cause a substantial release of calcein during the three hour period between liposome administration and tissue excision. It is notable that although significant portion of the observed release may be rapid and extracellular, when the $\mathrm{pH}$ is made acidic, there may be an additional small level release contributed from any PLNs that may have been taken up into cells causing a slower release from within the intracellular compartments.

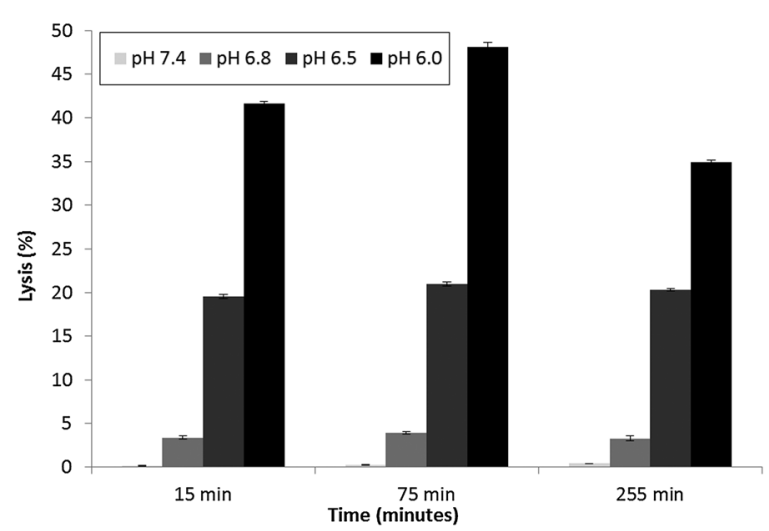

Fig. 8 Freshly prepared PLNs at a lipid to peptide ratio of $864: 1$ were incubated with an equal volume of mouse plasma. The plasma incubates $(10 \mu \mathrm{l})$ were dispensing into micro-wells and incubated for various time intervals in $180 \mu \mathrm{l}$ of buffer comprising $10 \mathrm{mM}$ sodium citrate phosphate supplemented with $140 \mathrm{mM} \mathrm{NaCl}, 5 \mathrm{mM} \mathrm{HEPES}$ and $1 \mathrm{mM}$ EDTA and adjusted to $\mathrm{pH} 7.4,6.8,6.5$ and 6.0. Fluorescence emission was recorded Ex $485 \mathrm{~nm}$ Em $535 \mathrm{~nm}$ and expressed as \% lysis. The mean of 4 replicates is presented, and error bars indicate the standard deviation. 


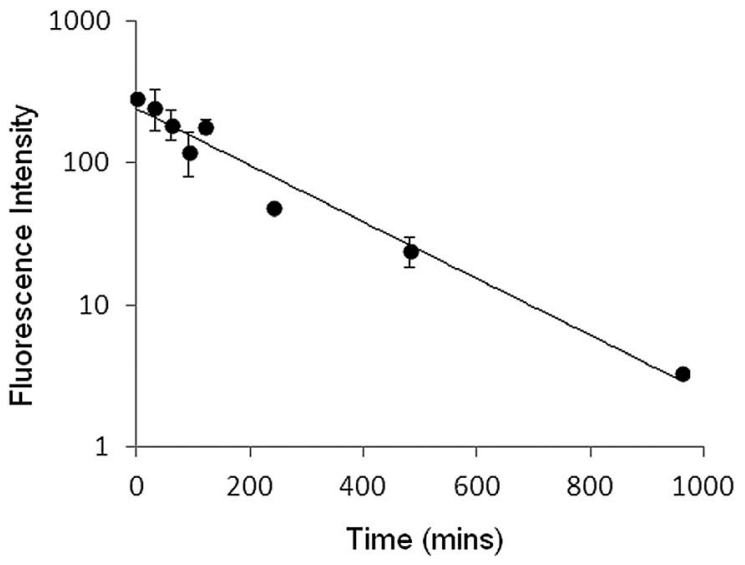

Fig. 9 Total calcein fluorescence remaining in plasma after intravenous administration of calcein-Dil liposomes. Fluorescence was measured from plasma samples at various time points after releasing calcein with Triton $(0.1 \% \mathrm{v} / \mathrm{v}) \mathrm{X}-100$. Each set point reflects the mean and standard deviation from 3 mice.
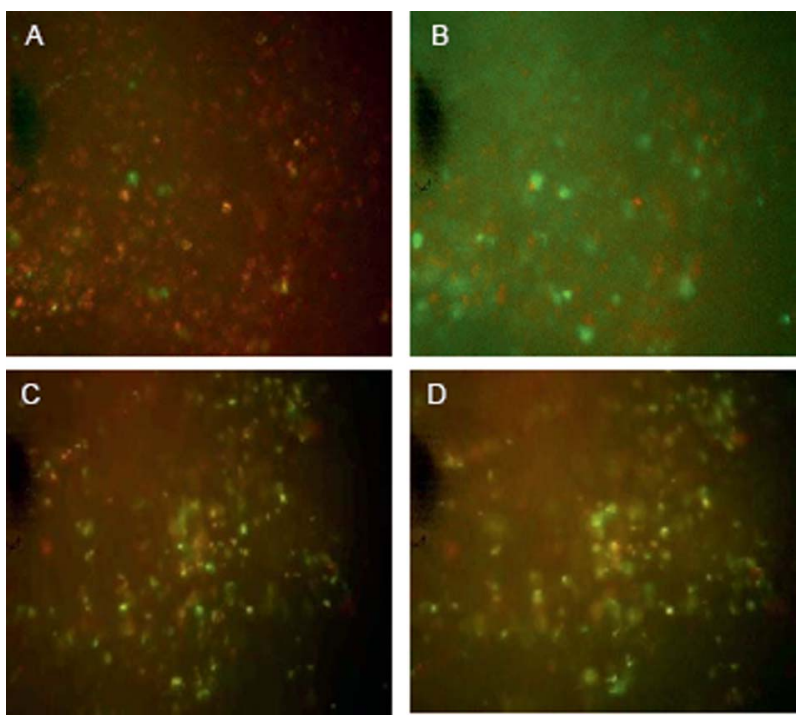

Fig. 10 Fluorescence photomicrographs of a KHT tumour section ( 60-100 $\mu \mathrm{m}$ ) excised $3 \mathrm{~h}$ after treatment with PLNs (A and B) or liposomes alone ( $C$ and $D$ ) and transferred to chamber perfused with PBS pH 8.0 (left panels) and same tumour section after replacing the solution in the perfusion chamber with fresh buffer at $\mathrm{pH} 5.8$ (right panels) and leaving for 20 minutes. The photomicrographs were taken from the same field using fluorescein filter and show a snapshot, 20 minutes after incubation, of the calcein diffusion.

\section{Validation of intra-tumoral $\mathbf{p H}$}

To demonstrate in vivo triggering of calcein release, under mildly acidic conditions, a suitable well-characterised tumour model was sought. Previous reports in the literature indicated that the combination of the mitochondrial respiratory inhibitor meta-iodobenzylguanidine (MIBG) with hyperglycemia significantly enhanced extracellular acidification in rodent radiationinduced fibrosarcoma (RIF-1) tumours, while only transient or modest effects were exerted upon normal tissues., ${ }^{2,16}$
Such treatment was reported to decrease the $\mathrm{pH}$ of interstitial fluid by 0.55 units. To validate the use of this model tumour system and demonstrate micro-environment triggered calcein release, a series of experiments were performed to confirm the repeatability of $\mathrm{pH}$ in this model. In mice bearing RIF-1 tumours, needle-electrode $\mathrm{pH}$ measurements detected significant acidification at 4 hours after MIBG/glucose as summarised in Table 3. Sham-treated tumour $\mathrm{pH}$ was significantly more acidic than non-tumour (muscle) tissue, by $0.21 \mathrm{pH}$ units. The MIBG/glucose treatment further reduced the tumour $\mathrm{pH}$ by 0.42 units below that of normal muscle tissue $\mathrm{pH}$ to reach a value of 6.57. These levels of tumour tissue acidification were statistically significant $(p<0.01)$.

It is worth mentioning that experiments were also performed with KHT allograft but the difference between the muscle tissue and tumour $\mathrm{pH}$ was found to be significantly smaller $(-0.28$ unit, $p<0.01$, paired one-tailed $t$-test). Given that the intratumoral acidity differences (Table 3 ) were of sufficient magnitude to nearly approach the $\mathrm{pH}$ value of 6.5 where calcein release in plasma was provoked (Fig. 8) and that PLNs can accumulate and remain responsive to $\mathrm{pH}$ in tumour microvasculature (Fig. 10), triggered release of calcein from PLNs in vivo was tested.

\section{Release of calcein in response to RIF tumour $\mathbf{p H}$}

To quantitatively assess calcein release from the PLNs, fluorescence changes were monitored by intravital fluorescence microscopy via the dorsal skin-fold window chambers fitted on mice with RIF-1 xenograft implants. ${ }^{\mathbf{2 4 2 6}}$ Alternating measurements of red and green fluorescence intensities were taken, every 30 seconds following intravenous (IV) injection to mice with implanted RIF-1 tumour allografts. Development of tumour fluorescence was immediately observed (Fig. 11) due to vascular filing of tissues which is known to occur, largely within $2 \min ^{36}$ Use of membrane-associated fluorophore, DiI as a red fluorescence marker of liposome accumulation is well documented. ${ }^{37}$ In the MIBG/glucose treated tumours, dual fluorescence images typically showed significant increases in bright green calcein fluorescence (Fig. 11 lower panel, B).

In contrast, only modest release of calcein was observed when liposomes alone without peptide were administered (Fig. 11, upper panel, A). Pixel intensities in such images were averaged to monitor calcein and DiI fluorescence signals. The normalised ratio of calcein (contents release) to DiI (accumulation) would then quantitatively reflect the release of calcein payload. Promptly following IV administration filling of the vascular compartment of the tissue a rapid step change in both

Table 3 Summary of tissue $\mathrm{pH}$ measurements in RIF tumour-bearing mice. Errors are one standard deviation. $N=6$ for each group ( 3 receive control liposomes, 3 receive complex)

\begin{tabular}{llll}
\hline Treatment & RIF tumour $\mathrm{pH}$ & Muscle $\mathrm{pH}$ & Difference \\
\hline Untreated & $6.80 \pm 0.06$ & $7.01 \pm 0.08$ & -0.21 \\
MIBG/glucose & $6.57 \pm 0.09$ & $7.00 \pm 0.23$ & -0.42
\end{tabular}




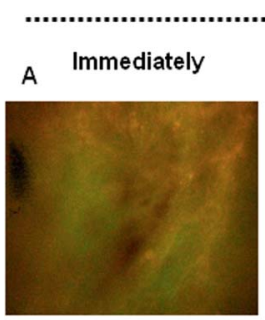

Time after injection

2 minutes
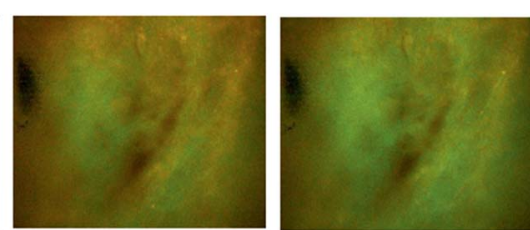

B
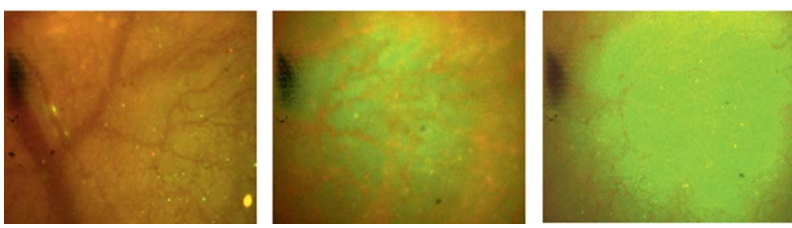

Fig. 11 Photomicrographs of a tumour transplanted in a mouse skin flap window chamber showing dual epifluorescence images following the delivery of liposomes (panel A) and PLNs (panel B) to a RIF tumour allograft in the window chamber. MIBG $\left(40 \mathrm{mg} \mathrm{kg}^{-1}\right)$ plus glucose $(1.5$ $\mathrm{g} \mathrm{kg}^{-1}$ ) treatment was administered in PBS pH 7.4 buffer three hours prior to injecting liposomes or PLNs at a dose of $0.4 \mu$ mole lipid. Images are shown at time points 0 (immediately), 2 and 20 minutes post injection.

DiI and calcein fluorescence was observed (arrow in Fig. 12). Subsequently, a slow increase or decrease of DiI fluorescence occurred, reflecting the combined effects of plasma clearance, tending to reduce intensity, and extravasations into interstitial space or uptake into cells, tending to increase intensity.

Normalising calcein fluorescence against DiI fluorescence provides a means of minimising variations associated with accumulation or clearance of the liposomes. Normalised dual fluorescence ratiometric kinetic plots were computed by taking the ratio immediately after the step increase in tissue fluorescence as exemplified in Fig. 12 (indicated by an arrow), to be equal to one. The data shown in Fig. 12 thus generates a

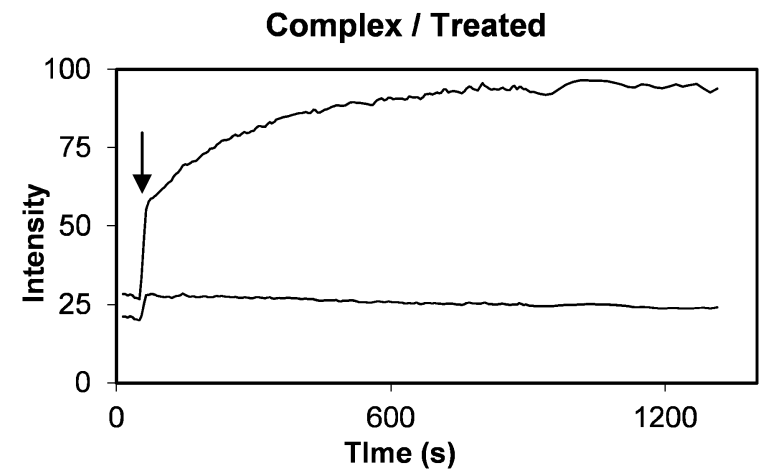

Fig. 12 Kinetic plot showing calcein (top curve) and Dil (bottom curve) tissue fluorescence intensity as a function of time following delivery of PLNs to a RIF tumour allograft. MIBG (40 $\mathrm{mg} \mathrm{kg}^{-1}$ ) plus glucose (1.5 g $\mathrm{kg}^{-1}$ ) treatment was administered in PBS $\mathrm{pH} 7.4$ buffer three hours prior to injecting PLNs at a dose of $0.4 \mu$ mole lipid. The normalised ratio plot of this data is shown in Fig. $13(+)$ taking the ratio of calcein to Dil fluorescence at the step change marked by arrow as one unit. normalised kinetic plot Fig. 13b represented by $(+)$ indicating significant release of calcein.

Fig. 13 represents data using six different window chambers. Those tumours that received control liposomes (chart A) showed a small change in normalised fluorescence, typically less than $25 \%$ increase, irrespective of the MIBG/glucose treatment. Moreover, tumours, without the MIBG/glucose treatment, administered with PLNs also showed a similar $(<25 \%)$ weak release of calcein (chart A, squares). In contrast, PLNs accumulating in MIBG/glucose-treated tumours (chart B) exhibited significantly ( $p<0.001$ by unpaired $t$-test) higher peak normalised calcein between 1.5 and 2. This represents an apparent maximum enhancement of up to 4-fold increased release of calcein in response to MIBG/glucose modulated tumour acidity. The results suggest that this release is likely to be due to the interaction of the $\mathrm{P} 4$ peptide and liposomes within the acidified tumour interstitial microenvironment. The consensus in the literature $^{38}$ is that the pathophysiological changes in average tumour $\mathrm{pH}$ pertain to the interstitial fluid and not the regulated intracellular compartment. The $\mathrm{pH}$ needle electrode measurements (Table 3) reported here indicated that the average tumour extracellular $\mathrm{pH}$ was 6.57 , a reduction of approximately 0.4 units compared to normal muscle. As the vascular compartment of the tumour must be maintained at physiological $\mathrm{pH}$, it can be inferred that in some regions of the tumour interstitium, the $\mathrm{pH}$ is significantly below this recorded average. For example in a tumour xenograft model, Helmlinger et al. ${ }^{39}$ measured a steep microscopic $\mathrm{pH}$ gradient from physiological $(\mathrm{pH}$ 7.4) to acidic as a function of distance from the nearest tumour micro-vessel.

The most plausible explanation for the enhanced release of calcein is that the peptide incorporated into the liposomes responded to the lowered interstitial $\mathrm{pH}$ to trigger the contents release into the extracellular compartment of the tumour. Further, evidence that the bulk of the release is extracellular was provided by the ex vivo studies of excised tissue in perfusion chambers, which showed that the calcein released during exposure to pH 5.8 buffer was washed away as the chamber was flushed with additional buffer. As the cell membrane is impermeable to calcein, any contents released from liposomes after cellular uptake are expected to remain in the tissue, and hence are not subject to removal by perfusion. Indeed small levels of intracellular fluorescence can be noted in the sliced tissue (Fig. 10) while the major calcein release was initiated only with pH 5.8 buffer. Again in vivo the main proportion of peptidetriggered release occurred rapidly, in less than 30 minutes after injection, compared to the internalisation of regular liposomes, where release is reported to occur over several hours. ${ }^{\mathbf{9 1 3}, 14}$ Thus the rapidity of calcein release also corroborates the significant proportion of the calcein release to be within the tumour interstitial fluid.

\section{Conclusions}

In the quest for effective liposome-based drug-delivery vehicles, a major objective is to produce liposomes that are sensitive to physiologically-relevant changes in microenvironment. Taken together, the results presented here show that a peptide can be 
(A) Controls : liposomes only (treated \& untreated) PLNs (untreated)

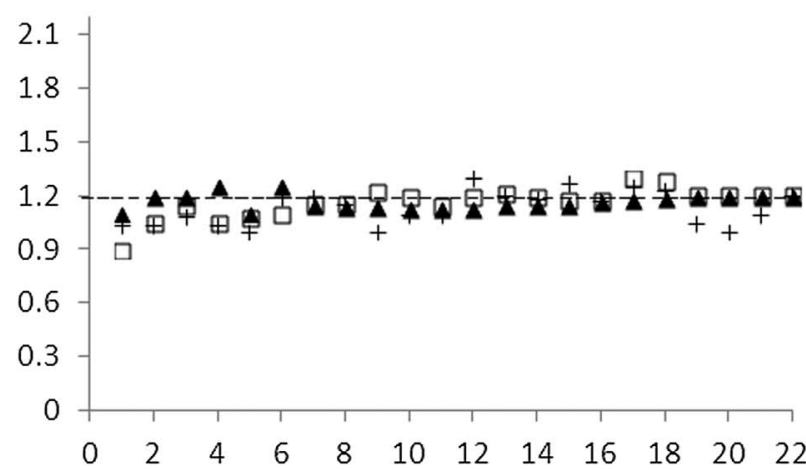

(B) PLNs treated

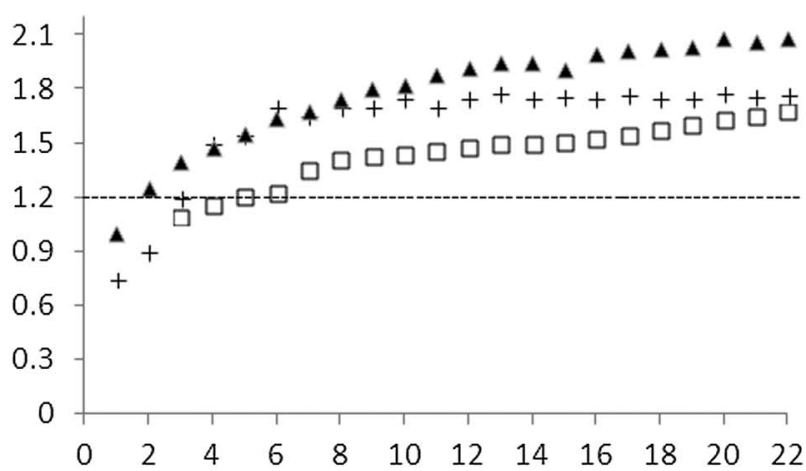

Fig. 13 Normalised kinetic plot showing ratio of calcein to Dil tissue fluorescence intensity as a function of time (in minutes) following delivery of liposomes alone. Data is obtained from six animals implanted with a RIF tumour allograft and fitted with a window chamber in the skin fold. Four of the animals were treated with MIBG $\left(40 \mathrm{mg} \mathrm{kg}^{-1}\right)$ plus glucose $\left(1.5 \mathrm{~g} \mathrm{~kg}^{-1}\right)$ treatment three hours prior to injecting liposomes or PLNs at a dose of $0.4 \mu$ mole lipid. The remaining two untreated animals received PBS pH 7.4 buffer instead. Chart A represents control experiments; ( + ) control liposomes and untreated, $(\mathbf{\Delta})$ control liposomes and MIBG/glucose treated and ( $\square$ ) PLNs untreated. Chart B has all three subjects which received PLNs and MIBG/glucose treatment. The normalised ratio is obtained by dividing the contents signal by the liposome signal and indicates changes in fluorescence intensity due to content release.

"tuned" to destabilise membranes at a pH slightly below that of normal tissue while having the ability to associate with liposomes to comprise peptide liposome nanoparticles (PLNs). The PLNs present in tumour vasculature remained functional after several hours of circulating in blood. Moreover a rapid $\mathrm{pH}^{-}$ triggered release of liposome contents slightly below the lowered $\mathrm{pH}$ expected in the tumour interstitial space was evident. The in vivo measurements in this study are limited to the tumour implanted window chamber. However the need for MIBG/glucose treatment to trigger calcein release and the fact that extracellular $\mathrm{pH}$ is more tightly regulated in normal tissue together with the lack or reduced level of liposome accumulation in most normal tissues provides assurance that the tumour site is the prime target. It is not suggested that this system, designed to validate the PLNs function, constitutes a viable therapeutic delivery system in its present form. The main limiting factor for practical applications in drug delivery system will be the short shelf-life of the PLNs as a single reagent particularly as the interaction between peptide and liposomes is reversible. However, given that such nanoparticles appear to respond close to patho-physiological conditions, the study does provide incentive to develop better formulation strategies in the future.

The recent work by Huang et al. (2013) assures some degree of success for using PLNs in vivo. These authors used a melittin analogue in combination with lipid nanoparticles to achieve efficacy against melanoma in tumour bearing mice. ${ }^{44}$ The interest in using peptides to render liposomes bio-responsive is rekindling. Recently Al-Ahmady et $a l .{ }^{40}$ incorporated a leucine zipper type peptide into temperature sensitive liposomes as a means to fine tune the release of encapsulated doxorubicin in response to mild hyperthermia. The onset of such triggered release was linked to the unfolding of peptide's helix structure. New perspectives, such as the recent work of Lin et al. ${ }^{27}$ highlighting the possibility of multifunctional self-assembled nanoparticles in which the fate of liposomes and GALA peptide are coupled as one through double acyl chains and a study by Etzerodt et al. ${ }^{28}$ demonstrating that dimyristoyl GALA peptide can be incorporated into the lipid bilayer during liposome preparation, are providing additional design considerations for potentially more stable $\mathrm{pH}$-sensitive PLNs in the future.

\section{Acknowledgements}

We thank Dr David Gough and Dr Robert Bonser for constructive discussions and Vectura Ltd for financial support. This work was also supported by BBSRC studentship (BBS/S/M/2004/ 11418) to Dr Shaun Offerman. We are also grateful to Professor Gillian Tozer and Professor Mark Dewhirst for assistance in establishing the mouse dorsal window chamber model, and to the Experimental Oncology Group at Manchester University for providing KHT and RIF-1 tumor cell lines.

\section{Notes and references}

1 M. Stubbs, P. M. J. McSheehy, J. R. Griffiths and C. L. Bashford, Mol. Med. Today, 2000, 6, 15-19.

2 I. F. Tannock and D. Rotin, Cancer Res., 1989, 49, 4373-4384.

3 T. Henning, M. Kraus, M. Brischwein, A. M. Otto and B. Wolf, Anti-Cancer Drugs, 2004, 15(1), 7-14.

4 T. Kaasgaard and T. L. Andresen, Expert Opin. Drug Delivery, 2010, 7(2), 225-243.

5 E. S. Lee, Z. Gao and Y. H. Bae, J. Controlled Release, 2008, 132(3), 164-170.

6 T. Ta and T. M. Porter, J. Controlled Release, 2013, 169(1-2), 112-125.

7 D. C. Drummond, M. Zignani and J. Leroux, Prog. Lipid Res., 2000, 39, 409-460. 
8 P. Meers, Adv. Drug Delivery Rev., 2001, 53, 265-272.

9 T. L. Andresen, S. S. Jensen and K. Jógensen, Prog. Lipid Res., 2005, 44, 68-97.

10 F. Yuan, M. Leunig, S. Huang, D. Berk, D. Papahadjopoulos and R. Jain, Cancer Res., 1994, 54, 3352-3356.

11 S. K. Huang, K. D. Lee, K. Hong, D. S. Friend and D. Papahadjopoulos, Cancer Res., 1992, 52, 5135-5143.

12 D. Lasic and D. Papahadjopoulos, Medical Applications of Liposomes, Elsevier Science, New York, NY, 1998.

13 M. J. Parr, D. Masin, P. R. Cullis and M. B. Bally, J. Pharmacol. Exp. Ther., 1997, 280, 1319-1327.

14 W. C. Zamboni, A. C. Gervais, M. J. Egorin, J. H. Schellens, E. G. Zuhowski, D. Pluim, E. Joseph, D. R. Hamburger, P. K. Working, G. Colbern, M. E. Tonda, D. M. Potter and J. L. Eiseman, Cancer Chemother. Pharmacol., 2004, 53, 329-336.

15 W. Li, F. Nicol and F. C. Szoka, Jr, Adv. Drug Delivery Rev., 2004, 56, 967-985.

16 A. Kuin, L. Smets, T. Volk, A. Paans, G. Adams, A. Atema, E. Jahde, A. Maas, M. F. Rajewsky, G. Visser and B. Wood, Cancer Res., 1994, 54, 3785-3792.

17 R. A. Parente, S. Nir and F. C. Szoka, Jr, Biochemistry, 1990, 29, 8720-8728.

18 M. J. Turk, J. A. Reddy, J. A. Chmielewski and P. S. Low, Biochim. Biophys. Acta, Biomembr., 2002, 1559, 56-68.

19 T. Kakudo, S. Chaki, S. Futaki, I. Nakase, K. Akaji, T. Kawakami, K. Maruyama, H. Kamiya and H. Harashima, Biochemistry, 2004, 43, 5618-5628.

20 C. Puyal, L. Maurin, G. Miquel, A. Bienvenue and J. Philippot, Biochim. Biophys. Acta, Biomembr., 1994, 1195, 259-266.

21 H. S. Aojula, S. Offerman, R. R. Aojula, A. P. Hutchinson, S. Nicklin and D. J. Clarke, Biochim. Biophys. Acta, Biomembr., 2002, 1564, 73-81.

22 J. C. Stewart, Anal. Biochem., 1980, 104, 10-14.

23 Y. H. Chen, J. T. Yang and H. M. Martíez, Biochemistry, 1972, 11, 4120-4131.

24 D. A. Berk, F. Yuan, M. Leunig and R. K. Jain, Proc. Natl. Acad. Sci. U. S. A., 1997, 94(5), 1785-1790.

25 M. H. Gaber, N. Z. Wu, K. Hong, S. K. Huang, M. W. Dewhirst and D. Papahadjopoulos, Int. J. Radiat. Oncol., Biol., Phys., 1996, 36, 1177-1187.
26 K. Djanashvili, T. L. M. ten Hagen, R. Blangé, D. Schipper, J. A. Peters and G. A. Koning, Bioorg. Med. Chem., 2011, 19, 1123-1130.

27 B. F. Lin, D. Missirlis, D. V. Krogstad and M. Tirrell, Biochemistry, 2012, 51(23), 4658-4668.

28 T. P. Etzerodt, S. Trier, J. R. Henriksen and T. L. Andresen, Soft Matter, 2012, 8(21), 5933-5939.

29 V. Munoz and L. Serrano, J. Mol. Biol., 1995, 245(3), 297-308.

30 N. K. Subbarao, R. A. Parente, F. C. Szoka, Jr, L. Nadasdi and K. Pongracz, Biochemistry, 1987, 26, 2964-2972.

31 R. A. Parente, S. Nir and F. C. Szoka, J. Biol. Chem., 1988, 263, 4724-4730.

32 O. Ishida, K. Maruyama, K. Sasaki and M. Iwatsuru, Int. J. Pharm., 1999, 190, 49-56.

33 A. Nagayasu, K. Uchiyama and K. Kiwada, Adv. Drug Delivery Rev., 1999, 40, 75-87.

34 S. J. Lunt, C. Cawthorne, M. Ali, B. A. Telfer, M. Babur, A. Smigova, et al., Br. J. Cancer, 2010, 103, 201-208.

35 T. Kalliomäki and R. P. Hill, Br. J. Cancer, 2004, 90, 18421849.

36 D. B. S. Pink, W. Schulte, M. H. Parseghian, A. Zijlstra and J. D. Lewis, PLoS One, 2012, 7, e33760, DOI: 10.1371/ journal.pone.0033760.

37 S. Shan, C. Flowers, C. D. Peltz, H. Sweet, N. Maurer, E. J. Kwon, A. Krol, F. Yuan and M. W. Dewhirst, Cancer Chemother. Pharmacol., 2006, 58, 245-255.

38 L. E. Gerweck and K. Seetharaman, Cancer Res., 1996, 56, 1194-1197.

39 G. Helmlinger, F. Yuan, M. Dellian and R. K. Jain, Nat. Med., 1997, 3, 177-182.

40 Z. S. Al-Ahmady, W. T. Al-Jamal, J. V. Bossche, T. T. Bui, A. F. Drake, A. J. Mason and K. Kostarelos, ACS Nano, 2012, 6, 9335-9346.

41 F. Nicol, S. Nir and F. C. Szoka, Biophys. J., 1996, 71, 32883301.

42 C. N. Pace, G. R. Grimsley and J. M. Scholtz, J. Biol. Chem., 2009, 284, 13285-13289.

43 V. Iacobucci, F. D. Giuseppe, T. T. Bui, L. S. Vermeer, J. Patel, D. Scherman, A. Kichler, A. F. Drake and A. J. Mason, Biochim. Biophys.Acta, Biomembr., 2012, 1818, 1332-1341.

44 C. Huang, H. Jin, Y. Qian, S. Qi, H. Luo, Q. Luo and Z. Zhang, ACS Nano, 2013, 7, 5791-5800. 